\title{
TOTAL PLATE COUNT OF COMMERCIAL PASTEURIZED MILK SOLD BY STREET VENDORS IN MULYOREJO SUB-DISTRICT SURABAYA
}

\author{
TOTAL PLATE COUNT DARI SUSU PASTEURISASI KOMERSIAL \\ YANG DIJUAL PEDAGANG KAKI LIMA DI KECAMATAN \\ MULYOREJO SURABAYA
}

Received: 10/10/2020; Revised: 10/11/2020; Accepted:27/04/2021; Published: 30/11/2021

Lailatul Maghfiroh ${ }^{1}$, A. T. Soelih Estoepangestie ${ }^{2 *}$, Tri Nurhajati ${ }^{3}$, Nenny Harijani², Mustofa Helmi Effendi ${ }^{2}$, Didik Handijatno ${ }^{4}$

${ }^{1}$ Bachelor Program, Faculty of Veterinary Medicine, Universitas Airlangga

${ }^{2}$ Department of Veterinary Public Health, Faculty of Veterinary Medicine, Universitas Airlangga

${ }^{3}$ Department of Animal Husbandry, Faculty of Veterinary Medicine, Universitas Airlangga

${ }^{4}$ Department of Veterinary Microbiology, Faculty of Veterinary Medicine, Universitas Airlangga

Kampus C UNAIR, Jalan Dr. Ir. Soekarno, Surabaya-60115, Indonesia

*Corresponding author: soelih.estoepangestie@gmail.com

\begin{abstract}
Food and nutritional quality of society is one of mine focuses of the government. Milk have complete nutrients but also can be the source food borne disease. The Veterinary Public Health itself has the responsibility to provide guarantees of food safety from animal resources which is called ASUH (safe, healthy, wholesome and halal) to be consumed by society. This study aimed to know the Total Plate Count of commercial pasteurized milk sold by street vendors in Mulyorejo Sub-district Surabaya. The study was conducted from January until February 2018 at the Laboratory of Veterinary Public Health Department, Faculty of Veterinary Medicine, Universitas Airlangga. Thirty samples of commercial pasteurized milk were bought from three street vendors then examined using Pour Plate Method of Total Plate Count. Total Plate Count result showed that the number of bacteria in commercial pasteurized milk sold by street vendors in Mulyorejo Sub-district Surabaya was $1.0 \times 10^{4} \mathrm{CFU} / \mathrm{ml}$, that met the National Standard of Indonesia (SNI) 01-3951-1995.
\end{abstract}

Keywords: Total plate count, pasteurized milk, number of bacteria

\section{ABSTRAK}

Kualitas pangan dan gizi masyarakat merupakan salah satu fokus perhatian pemerintah. Susu memiliki nutrisi yang lengkap, namun juga dapat menjadi sumber penyakit bawaan makanan. Kesehatan Masyarakat Veteriner sendiri memiliki tanggung jawab untuk memberikan jaminan keamanan pangan dari sumber hewani yang disebut ASUH (aman, sehat, utuh, dan halal) sehingga dapat dikonsumsi masyarakat. Penelitian ini bertujuan untuk mengetahui Total Plate Count susu pasteurisasi komersial yang dijual oleh pedagang kaki lima di Kecamatan Mulyorejo Surabaya. Penelitian dilaksanakan pada bulan Januari sampai Februari 2018 di Laboratorium Kesehatan Masyarakat Veteriner Fakultas Kedokteran Hewan Universitas Airlangga. Tiga puluh sampel susu pasteurisasi komersial dibeli dari tiga pedagang kaki lima kemudian diperiksa menggunakan Metode Pour Plate Total Plate Count. Hasil Total Plate Count menunjukkan bahwa jumlah bakteri pada susu pasteurisasi komersial yang dijual oleh pedagang kaki lima di Kecamatan Mulyorejo Surabaya adalah $1,0 \times 10^{4} \mathrm{CFU} / \mathrm{ml}$, yang memenuhi Standar Nasional Indonesia (SNI) 01-3951-1995.

Kata kunci: Total plate count, susu pasteurisasi, jumlah bakteri 
How to cite: Maghfiroh, L., Estoepangestie, ATS., Nurhajati, T., Harijani, N. 2021. Total Plate Count of Commercial Pasteurized Milk Sold by Street Vendors in Mulyorejo Sub-District Surabaya. Journal of Halal Product and Research. 4(2), 56-61, https://dx.doi.org/10.20473/jhpr.vol.4issue.2.56-61.

\section{INTRODUCTION}

Nowadays, issues of food and nutritional quality of the society is one of the main focuses of the government. Based on Act 36 of 2009, one of the national development priorities is the improvement of society's nutrition status. The Veterinary Public Health itself has the responsibility to provide guarantees of food safety from animal resources which is called ASUH (safe, sound, wholesome and halal) to be consumed by society (Wuryaningsih, 2010).

Milk, as one source of food, is very important to meet the protein needs of society. The complete nutritional content in milk such as carbohydrates, proteins, fats, vitamins, water and minerals can increase the nutritional growth of society. However, the complete nutrition content in milk, causing milk to be a good medium for bacterial growth. According to Azwar, (2014) milk has a lot of nutrients, but during its storage, it is easily damaged by bacteria that grow in cold temperatures, such as Pseudomonas sp.

Cases of poisoning after drinking pasteurized milk occur in 20 students of SDN Pandanrejo 1 on September 6, 2017, this is because the milk is acidic and close to expiration date, until they have symptoms of vomiting, weakness, dizziness and rushed to Puskesmas Bumiaji, Batu. (Putri, 2017).

Based on research conducted by Abubakar et al., (2001) the number of bacteria in fresh milk and pasteurized milk packaging sold by the street vendors in West Java, exceeds the maximum limit of microbial contamination of National Standard of Indonesia in 2000 that is $3.7 \times 10^{6} \mathrm{CFU} / \mathrm{ml}$ for fresh milk and $3.4 \times 10^{6} \mathrm{CFU} / \mathrm{ml}$ for pasteurized milk. Then, based on Mastuti, (2007) the pasteurized milk products in plastic containers that were distributed in Malang exceeds the standard of bacterial contain set by the government.

Pasteurized milk is milk that has been heated at $63^{\circ} \mathrm{C}$ for 15 minutes (LTLT) or heated at $72^{\circ} \mathrm{C}$ for 15 seconds (HTST). Pasteurization is a process to kill all microorganisms either spoilage or pathogens (Chotiah, 2014). Pasteurization process can decrease the number of pathogenic bacteria, but pasteurized milk may be contaminated by microorganisms after processing, during packing, transport and storage temperature have an effect on the proliferation of heating resistant microorganisms and heat-resistant spores such as Staphylococcus aureus (Hanum et al, 2017).

In Mulyorejo Sub-districts Surabaya, it is found some street vendors of commercial pasteurized milk. The location of Mulyorejo Sub-district itself is strategic for sale this product because it is located in downtown of Surabaya. Commercial pasteurized milk sold in Mulyorejo Sub-district became one of the fulfillment of the milk needs of society. In addition, there has never been a research report on the total number of bacteria in commercial pasteurized milk sold by street vendors in the Mulyorejo Subdistrict Surabaya.

Total Plate Count is one of the methods used in microbiological test that determine the shelf life, sanitation and milk safety indicators (Prawesthirini et al., 2016). TPC is intended to show the number of bacteria contained in a product by calculating bacterial colonies that grow on agar medium and can be seen directly without using a microscope (Yunita et al., 2015).

Based on the background explanation above, it is important to do research on Total Plate Count of commercial pasteurized milk sold by street vendors in Mulyorejo Sub-district Surabaya. This study was aimed to know the quality of commercial pasteurized milk sold by street vendors in Mulyorejo Sub-district Surabaya based on TPC, meet the National Standard of Indonesia (SNI) 013951-1995 or not.

\section{MATERIALS AND METHODS}

The study was conducted from January to February 2018. Thirty samples of commercial pasteurized milk were bought from street vendors in Mulyorejo Sub-district Surabaya, $150 \mathrm{ml}$ each pack. Two samples were bought from each of the three street vendors, once a week. The sampling collection design was shown in Table 1.

Total Plate Count Examination was done at The Laboratory of Veterinary Public Health Department, Veterinary Medicine Faculty of Universitas Airlangga. 
Table 1. Purposive Sampling Size

\begin{tabular}{|c|c|c|c|}
\hline \multirow{2}{*}{ Weeks } & \multicolumn{3}{|c|}{ Street vendors } \\
\hline & 1 & 2 & 3 \\
\hline I & 2 samples & 2 samples & 2 samples \\
\hline II & 2 samples & 2 samples & 2 samples \\
\hline III & 2 samples & 2 samples & 2 samples \\
\hline IV & 2 samples & 2 samples & 2 samples \\
\hline $\mathbf{V}$ & 2 samples & 2 samples & 2 samples \\
\hline \multirow{2}{*}{$\begin{array}{c}\text { Total } \\
\text { samples }\end{array}$} & 10 samples & 10 samples & 10 samples \\
\hline & \multicolumn{3}{|c|}{30 samples } \\
\hline
\end{tabular}

This study used the Pour Plate Method. One $\mathrm{ml}$ of milk was diluted into $10^{-2}, 10^{-3}$, and $10^{-4}$ using diluent Buffered Peptone Water (Merck-1.07228.0500). Each dilution was dropped into a labeled sterile petri dish, then poured each with $15 \mathrm{ml}$ of Nutrient Agar (Merck-1.05450.0500) medium. All inoculated NA were incubated for 48 hours at $37^{\circ} \mathrm{C}$. Only petri dish with $30-300$ bacterial colonies were counted.

The result of bacterial calculation was compared to the standard of pasteurized milk SNI 013951-1995 based on the Total Plate Count.

\section{RESULTS}

Total Plate Count Examination showed the average results of bacterial numbers in 30 samples of commercial pasteurized milk sold by street vendors in Mulyorejo Sub-district Surabaya as shown in Table 2 and Figure 1 below.

Table 2. TPC Average of Commercial Pasteurized Milk Sold by Street Vendors in Mulyorejo Sub-district Surabaya

\begin{tabular}{|c|c|c|}
\hline Weeks & TPC Average (CFU/mI) & TPC Maximum Standard (CFU/ml) \\
\hline I & $1.3 \times 10^{4}$ & \\
\hline II & $1.2 \times 10^{4}$ & \\
\hline III & $1.7 \times 10^{4}$ & \multirow{2}{*}{$3.0 \times 10^{4}$} \\
\hline IV & $2.2 \times 10^{3}$ & \\
\hline V & $8.2 \times 10^{3}$ & \\
\hline Average & $\mathbf{1 . 0 \times 1 0 ^ { 4 }}$ & \\
\hline
\end{tabular}

TPC of commercial pasteurized milk sold by street vendors in Mulyorejo Sub-district Surabaya was $1.0 \times 10^{4} \mathrm{CFU} / \mathrm{ml}$, that met SNI $01-3951-1995$. Therefore, the quality of pasteurized milk is still considered as good and safe for people to consume.

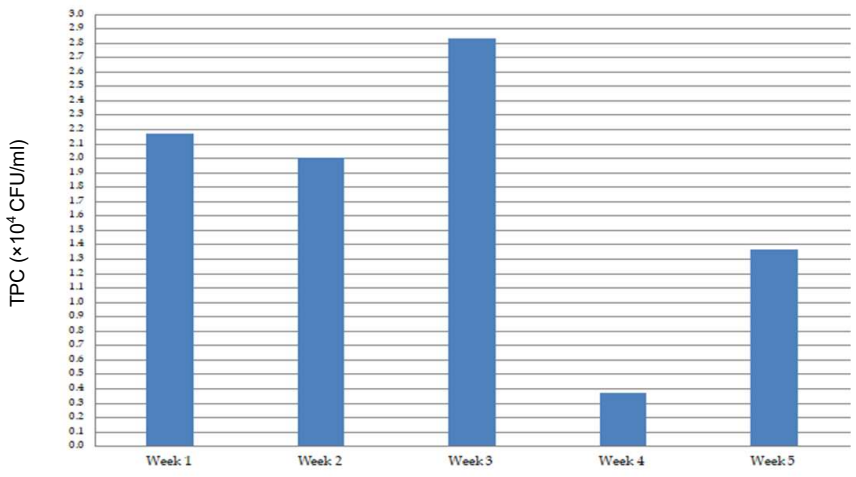

Figure 1. TPC Average each week from 30 samples of Commercial Pasteurized Milk Sold by Street Vendors in Mulyorejo Surabaya 
Based on Figure 1, it showed that the average number of highest TPC seen in the third week that was $1.7 \times 10^{4} \mathrm{CFU} / \mathrm{ml}$ and the average number of lowest TPC seen in the fourth week that was $2.2 \times 10^{3} \mathrm{CFU} / \mathrm{ml}$. In the third week Sample B showed the highest TPC with the value of $2.9 \times 10^{4}$ $\mathrm{CFU} / \mathrm{ml}$ which can be seen in Figure 2, and in the fourth week Sample C showed the lowest TPC with the value of $1.3 \times 10^{3} \mathrm{CFU} / \mathrm{ml}$ which can be seen in Figure 3 below.

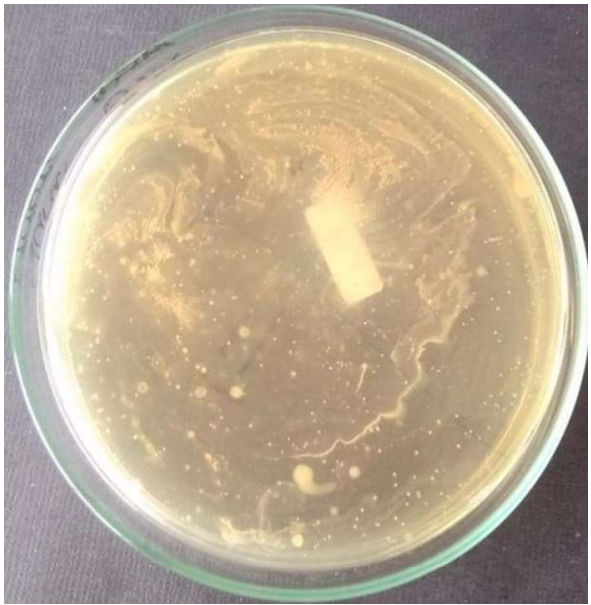

Figure 2. Nutrient Agar media showed the bacterial growth of sample $B$ in third week. The colonies of bacteria formed white dots and can be seen directly without microscope. The TPC value of this sample was $2.9 \times 10^{4} \mathrm{CFU} / \mathrm{ml}$.

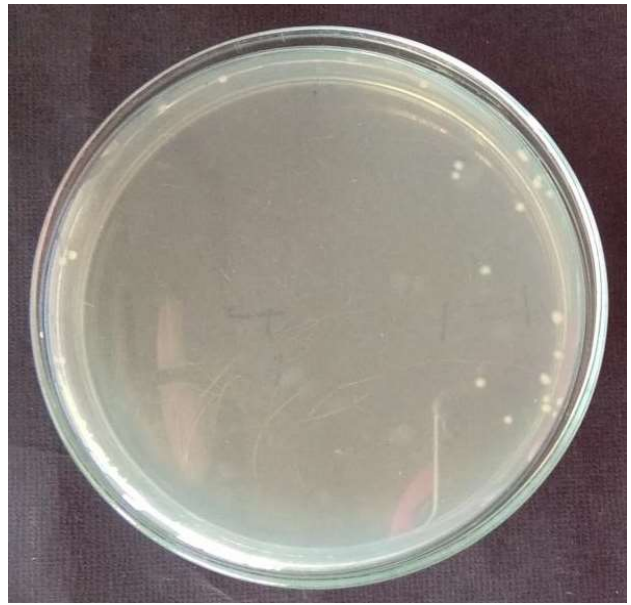

Figure 3. Nutrient Agar media showed the bacterial growth of sample $C$ in fourth week. The colonies of bacteria formed white dots and can be seen directly without microscope. The TPC value of this sample was $1.3 \times 10^{3} \mathrm{CFU} / \mathrm{ml}$

\section{DISCUSSION}

Based on the result above, the Total Plate Count calculation of 30 samples commercial pasteurized milk sold by street vendors in Mulyorejo Sub-district Surabaya did not exceed the standard maximum limit set by the National Standard Body that was under $3.0 \times 10^{4} \mathrm{CFU} / \mathrm{ml}$. The percentage of TPC of commercial pasteurized milk sold by street vendors in Mulyorejo Sub-dictrict Surabaya was $100 \%$ met the SNI 01-3951-1995.

The TPC average each week showed the difference of bacterial number as Figure 1. In the first week the average TPC result was $1.3 \times 10^{4} \mathrm{CFU} / \mathrm{ml}$. In the second week the average TPC result was $1.2 \times 10^{4} \mathrm{CFU} / \mathrm{ml}$. In the third week the average TPC result was $1.7 \times 10^{4} \mathrm{CFU} / \mathrm{ml}$. In the fourth week the average TPC result was $2.2 \times 10^{3} \mathrm{CFU} / \mathrm{ml}$. In the fifth week the average TPC result was $8.2 \times 10^{3} \mathrm{CFU} / \mathrm{ml}$.

Some factors that caused a different number of TPC are storage temperature and distribution time. The applied microbiological quality controls of pasteurized milk include storage temperatures, cooling methods during handling and production processes, packaging types, and potential of postproduction contamination (Budiyono, 2009). The distribution process also affects the different number of TPC. Transportation time is the length of time used to distribute milk from the factory to the supplier until it's sold to consumers. According to Shazari (2016), the time used to distribute milk to the consumer should be as fast as possible, because it is closely related to the development of bacteria.

In the third week (Figure 1) showed the highest TPC average that was $1.7 \times 10^{4} \mathrm{CFU} / \mathrm{ml}$. Particularly sample B in third week (Figure 2), showed the highest bacterial growth on Nutrient Agar media and TPC value was $2.9 \times 10^{4} \mathrm{CFU} / \mathrm{ml}$. This result was high and close to the maximum limit of SNI 01-3951-1995. The samples in third week were bought five days before expiration date.

According to Abubakar et al., (2001), high bacterial counts in pasteurized milk can be caused by improper pasteurization, poor of hygiene and sanitation, length of storage and temperature of storage after pasteurization. Pasteurization in general can reduce the number of bacteria $90-99 \%$ and it depends on the type and the number of bacteria before pasteurization. The bacterial growth in pasteurized milk depends on storage temperatures, quantities and bacteria that are resistant to pasteurization. 
According to Budiyono (2009), bacteria that resistant to heating under $100^{\circ} \mathrm{C}$ is thermoduric bacteria and spore-formers. Several types of thermoduric bacteria commonly found in raw milk such as Enterococcus, Micrococcus, Brevibacterium, and Lactobacillus. Spore-formers bacteria are common contaminants of food products, they can survive during pasteurization, for instance the species of Clostridium and Bacillus. However, it can be solved by a cooling process temperatures below $4^{\circ} \mathrm{C}$ in order to inhibit the growth of this bacterial type. In addition, there are also bacteria that are resistant to cool temperatures. Psychotropic is a major contaminant of dairy products, alive in milk cooling, but does not survive during pasteurization, and produces unpleasant flavors such as Pseudomonas (Kristanti et al., 2015).

In the fourth week (Figure 1), it showed the lowest TPC average value that was $2.2 \times 10^{3}$ $\mathrm{CFU} / \mathrm{ml}$. Particularly sample C in fourth week (Figure 3), showed the lowest of bacterial growth on Nutrient Agar media and TPC value was $1.3 \times 10^{3} \mathrm{CFU} / \mathrm{ml}$. This result was quite low when compared to the standard maximum limit of SNI 01-3951-1995. The samples in fourth week were bought twelve days before expiration date.

Based on Mastuti (2007), there are several factors that influence the low of bacterial contamination in pasteurized milk, such as good raw materials, perfect pasteurization process, good hygiene and sanitation during packaging process, standardized storage temperature, and good distribution process and good handling from the street vendors. According to Budiyono (2009), the quality of raw milk is determine by two important aspects, there are composition and microbial contamination, both must be in accordance with the standard of fresh milk set by National Standard Body namely SNI 01-3141-1998. Based on SNI 01-3141-1998, fresh milk has a minimum density of 1.0280 (at $27{ }^{\circ} \mathrm{C}$ ); minimum fat content of $3.0 \%$; minimum non-fat dry ingredients of $8.0 \%$; protein minimum 2,7\%; $\mathrm{pH} 6.3-6.8$; as well as the maximum number of bacteria is $1.0 \times 10^{6} \mathrm{CFU} / \mathrm{ml}$ and maximum number of inflammatory cell is $4.0 \times 10^{5} / \mathrm{ml}$.

The perfect pasteurization process also affects the low levels of bacterial contamination. The pasteurization process can kill $90-99 \%$ of bacteria and aim to kill pathogenic bacteria, to minimalize the loss of nutrients, and to maintain the physical properties and tastes contained in milk (Abubakar et al., 2001). In addition, cooling and storage processes at temperatures under $4^{\circ} \mathrm{C}$ can also inhibit bacterial growth and increase the length of milk storage (Syahriana, 2015).

\section{CONCLUSION}

Based on research results above, the Total Plate Count of commercial pasteurized milk sold by street vendors in Mulyorejo Sub-district Surabaya was $1 \times 10^{4} \mathrm{CFU} / \mathrm{ml}$ that met the National Standard of Indonesia (SNI) 01-3951-1995.

\section{ACKNOWLEDGEMENT}

Thanks to members of Veterinary Public Health Department: Dhandy Koesoemo W., drh., M.Vet., Mom Ersti Diani Wahyu A., Mr. Bagus for allowing and helping the author to complete the study with the resource, knowledge and support provided.

\section{REFERENCES}

Abubakar, Triyantini, R. Sinarlim, H. Setiyanto, and Nurjannah. 2001. Effect of Temperature and Time of Pastuerization on The Milk Quality During Storage. Journal of Animal and Veterinary Science. 6(1):45-50.

Azwar, Khoirul. 2014. Wrong risk of Consuming Milk. Newspaper Republika co.id. Retrieved from the page.republika.co.id /news/national/law/11/10/06/lifestyle-info-healthy/17/08/15/newspaper/ medika/14/09/22/ncagg9-wrong-consuming-milk.(September 23, 2017)

National Standard Body. 1995. SNI 01-3951-1995 Quality Standard of Pasteurized Milk. Jakarta

National Standard Body. 1998. SNI 01-3141-1998 Quality Standard of Fresh Milk. Jakarta

Buckle, K.A., Edwards R.A., Fleet G.H. and Wooton M. 1987. Food Science. H. Purnomo and Adiyono, Translator. Jakarta: UI Press.

Budiyono, Haris. 2009. Analysis of Pasteurized Milk Store Savings Based on Quality of Milk Quality Raw Material. Journal of Paradigm. 10(2).

Chotiah, Siti. 2014. Some Pathogenic Bacteria that May be Found in Cow's Milk and Its Prevention. Center for Veterinary Research, Bogor.

Kristanti N. D., Warnaen, A and Daning, D. R. A. 2015. Critical Control Point on Pasteurization Milk Processing at KUD-Dau Malang Regency. Animal Science. 15(1):1-7. 
Kristanti, Novita Dewi. 2017. Pasteurization Milk Store Saves the Quality of Microbial Thermodurics and Chemical Quality. Journal of Animal Science and Technology. 12(1): 1-7.

Mastuti, Rini. 2007. Bacterial Count of Pasteurized Milk Packed by Plastic Distributed in Malang Municipality. Faculty of Agriculture of Samudra Langsa University. Journal of Animal Products Science and Technology. 2(2): 52-57.

Prawesthirini, Soetji, Nenny H., Budiarto, Dadik R., M. Helmi E., A.T. soelih E. and Hario P. S. 2016. Practical Guidelines for Quality Analysis of Milk, Meat and Eggs. Faculty of Veterinary Medicine. Universitas Airlangga.

Putri, Sany Eka. 2017. Dozens of Students in Kota Batu Milk Poisoning, Tribunjatim.com. Accessed from page https://www. google.com/amp/jatim.tibunnews.com/amp/2017/09/06/breakig-news-adozen-students-in-townrocks-poisoning-milk. (14/10/2017)

Shazari, Putri Adelina. 2016. Comparison of the Number of Escherichia coli Bacteria in Pasteurized Cow Milk and Ultra High Temperature (UHT) Cow Milk Out in Bandar Lampung. Doctor Education Study Program. Medical School. University of Lampung.

Syahriana, sabil. 2015. Pasteurizing High Temperature Short Time Milk to Listeria monocytogenes on Refrigerator Storage. Faculty of Animal Husbandry. Universitas Hassanuddin. Makassar.

Wuryaningsih, Etty. 2010. Government Policy on Food Security of Animal Origin.Directorate of Kesmavet. Director General of Livestock, Ministry of Agriculture.

Yunita, Merisa, Yusuf Hendrawan, Rini Yulianingsih. 2015. Quantitative Analysis of Microbiology in Aerofood ACS of Garuda Indonesia Based on TPC (Total Plate Count) By Pour Plate Method. Journal of Tropical Agriculture and Biosystem Engineering. 3(3): 237-248. 